\title{
Health-promoting benefits of low-fat akawi cheese made by exopolysaccharide-producing probiotic Lactobacillus plantarum isolated from camel milk
}

\author{
Ayesha S. Al-Dhaheri, ${ }^{*}$ Reem Al-Hemeiri, $\dagger$ Jaleel Kizhakkayil, ${ }^{\star}$ Anas Al-Nabulsi, $\ddagger$ Aisha Abushelaibi, $\dagger$ \\ Nagendra P. Shah, $\S^{1}$ and Mutamed Ayyash $\dagger^{1}$ \\ ${ }^{*}$ Nutrition and Health Science Department, and \\ †Food Science Department, College of Food and Agriculture, United Arab Emirates University (UAEU), PO Box 1555, Al Ain, \\ United Arab Emirates \\ †Department of Nutrition and Food Technology, Jordan University of Science and Technology, Irbid 22110, Jordan \\ $\S F o o d$ and Nutritional Science, School of Biological Sciences, University of Hong Kong, Pokfulam Road, Hong Kong
}

\section{ABSTRACT}

Lactic acid bacteria isolated from camel milk exhibit remarkable probiotic and exopolysaccharide (EPS)-producing characteristics. The health-promoting benefits of exopolysaccharide-producing probiotic Lactobacillus plantarum isolated from camel milk used for making low-fat akawi cheese were investigated. Three low-fat akawi cheeses were made using traditional culture (nonEPS-producing, EPS ${ }^{-}$), commercial EPS-producing $\left(\mathrm{MEPS}^{+}\right)$, and camel milk EPS-producing $\left(\mathrm{CEPS}^{+}\right)$ cultures. $\alpha$-Amylase and $\alpha$-glucosidase inhibitory activities, antioxidant activities, angiotensin-converting enzyme (ACE) inhibition, and antiproliferative activity were determined. Cheese made with $\mathrm{CEPS}^{+}$culture exhibited comparable $\alpha$-amylase inhibition to that of cheeses made with $\mathrm{MEPS}^{+}$. Scavenging rates of cheese made with $\mathrm{EPS}^{+}$cultures were higher than those of cheese made with EPS $^{-}$cultures. The percentage of $\alpha$-glucosidase inhibition ranged from $>45 \%$ at $0 \mathrm{~d}$ to $\sim 55 \%$ at $21 \mathrm{~d}$ of storage. After $7 \mathrm{~d}$ of storage, the scavenging rate in $\mathrm{CEPS}^{+}$cheese increased $>60 \%$ by ABTS assay [2,2'-azino-bis(3-ethylbenzo-thiazoline-6-sulfonic acid)] and $>20 \%$ by DPPH assay (1,1-diphenyl2 -picrylhydrazyl). Throughout storage, cheese made with $\mathrm{EPS}^{+}$cultures showed higher ACE-inhibition activity compared with $\mathrm{EPS}^{-}$cultures. Cheese made with $\mathrm{CEPS}^{+}$showed ACE inhibition $>70 \%$ after $7 \mathrm{~d}$ of storage. Antiproliferation activity of $\mathrm{CEPS}^{+}$cheese increased from 38 to $48 \%$ during $7 \mathrm{~d}$ of storage and was maintained above $45 \%$ with prolonged storage. Low-fat akawi cheese produced with these cultures exhibited similar or greater health-promoting benefits compared

Received February 20, 2017

Accepted May 29, 2017.

${ }^{1}$ Corresponding authors: mutamed.ayyash@uaeu.ac.ae and npshah@hku.hk with cheese made using commercial starter cultures. Therefore, incorporation of these cultures in food is promising for commercial uses.

Key words: probiotic, exopolysaccharide (EPS), health-promoting benefit, antiproliferative

\section{INTRODUCTION}

Lactic acid bacteria (LAB) are extensively used to produce a wide range of dairy products such as fermented milk and cheeses. The proteolytic, lipolytic, and glycolytic activities of LAB (Ruas-Madiedo et al., 2002) contribute to flavor, texture, microstructure, and nutritious and health-promoting benefits of fermented dairy products, including cheese. Exopolysaccharides (EPS) produced by several LAB may significantly influence cheese attributes such as chemical composition, viscoelastic properties, sensory attributes, and healthpromoting properties. These EPS are either attached on the bacterial surface (capsular EPS) or released to the growth environment (ropy EPS), where they can act as a natural thickening agent or stabilizer (Duboc and Mollet, 2001). Therefore, EPS may improve the rheological and textural properties of low-fat cheese. In addition to their technical properties, EPS are reported to have novel physiological properties leading to exceptional health-promoting benefits, including antitumor, antiulcer, immune-modulating, and cholesterol-lowering activities, as well as being considered prebiotic (RuasMadiedo et al., 2002; Caggianiello et al., 2016). Dilna et al. (2015) reported antioxidant activity, $\alpha$-amylase inhibition, cholesterol lowering, and antiproliferative activities of EPS produced by Lactobacillus plantarum RJF4. The variation in health-promotion benefits of EPS depends on species, strain, and EPS type (Ryan et al., 2015b). Thus, new strains with novel EPS-producing properties will provide significant values to food industry. 
Several studies have reported technological functions and physiological properties of EPS in low-fat cheeses including Cheddar (Costa et al., 2010; Ryan et al., 2015a), Kasar (Şanli et al., 2013), mozzarella (Perry et al., 1998; Zisu and Shah, 2005), Prato (Nepomuceno et al., 2016), Mexican Panela (Jiménez-Guzmán et al., 2009), and Swiss-type (Ryan et al., 2015a) cheeses. Akawi cheese is a well-known Middle Eastern cheese that is extensively consumed by people in North Africa, Middle Eastern, and Gulf Cooperation Council countries (Abd El-Salam and Alichanidis, 2004). Low-fat akawi cheese is used as a major ingredient to prepare various types of sweets, especially Kunafah, which is very popular among people in the above-mentioned regions (Ayyash et al., 2012). To the best of our knowledge, no information is available about low-fat akawi cheese made with an EPS-producing culture. Nine LAB have been isolated from camel milk and identified as having robust probiotic characteristics and EPS production capabilities (Abushelaibi et al., 2017). Out of 9 LAB isolates, Lactobacillus plantarum KX881772 and Lb. plantarum KX881779 were found to be very promising and hence were used in the current study. The tests of $o$ phthalaldehyde (OPA); 1,1-diphenyl-2-picrylhydrazyl (DPPH) and 2,2'-azino-bis(3-ethylbenzo-thiazoline6 -sulfonic acid) (ABTS); $\alpha$-amylase and $\alpha$-glucosidase inhibition; angiotensin-converting enzyme (ACE) inhibition; and cytotoxicity against cell lines are recognized in vitro indicators for proteolytic activity (McSweeney and Fox, 1997); antioxidant (Power et al., 2013); antidiabetic (Lauritano and Ianora, 2016); antihypertensive (Gobbetti et al., 2004); and antiproliferative (Elfahri et al., 2016) activities, respectively. These indicators are used to evaluate in vitro health-promoting benefits of functional food products (Mohanty et al., 2016; Marcone et al., 2017). The objectives of this study were to investigate the health-promoting benefits ( $\alpha$-amylase and $\alpha$-glucosidase inhibitory activities, ACE-inhibitory activity, and antiproliferative activity) of low-fat akawi cheese made with EPS-producing $\left(\mathrm{EPS}^{+}\right)$probiotic $L b$. plantarum KX881772 and KX881779 strains isolated from camel milk $\left(\mathbf{C E P S}^{+}\right)$compared with a commercial EPS-producing culture $\left(\mathrm{MEPS}^{+}\right)$.

\section{MATERIALS AND METHODS}

\section{Culture Propagation}

Two white cheese cultures, White-Classic (non-EPSproducing, EPS ${ }^{-}$; Streptococcus thermophilus and Lactobacillus bulgaricus) and White-Daily commercial EPS-producing (MEPS ${ }^{+}$; Streptococcus thermophilus, Lactobacillus bulgaricus, and Lactococcus lactis ssp. lactis), were provided by Chr. Hansen Holding A/S (Hørsholm, Denmark) and 2 EPS-producing bacterial strains Lactobacillus plantarum KX881772 and KX881779 isolated from camel milk $\left(\mathrm{CEPS}^{+}\right.$; Abushelaibi et al., 2017) were used in the current study. The Lb. plantarum KX881772 and KX881779 strains were stored in de Man, Rogosa, and Sharpe (MRS) broth (Oxoid, Basingstoke, UK) with 50\% glycerol at $-80^{\circ} \mathrm{C}$. To activate the Lb. plantarum KX881772 and KX881779 $\left(\mathrm{CEPS}^{+}\right)$cultures, a $100-\mu \mathrm{L}$ aliquot of each culture was individually transferred into MRS broth and incubated at $37^{\circ} \mathrm{C}$ for $24 \mathrm{~h}$. A weekly culture transfer was carried out to maintain bacterial activity. For all cultures $\left(\mathrm{EPS}^{-}, \mathrm{MEPS}^{+}\right.$, and $\mathrm{CEPS}^{+}$) and before the experiments, 2 successive culture transfers were carried out in MRS broth, and a third transfer was in sterilized reconstituted skim milk ( $13 \% \mathrm{wt} / \mathrm{vol})$ and incubated at $37^{\circ} \mathrm{C}$ for $24 \mathrm{~h}$.

\section{Cheese Making}

Akawi cheese was manufactured according to the procedure described by Ayyash et al. (2012). Briefly, homogenized, pasteurized, low-fat (1\%) bovine milk was tempered to $40^{\circ} \mathrm{C}$. Bacterial culture was added at $1 \%$ ( vol/vol) and mixed for $2 \mathrm{~min}$. Three batches of cheese were made using $\mathrm{EPS}^{-}, \mathrm{MEPS}^{+}$, and $\mathrm{CEPS}^{+}$ (Lb. plantarum KX881772 and KX881779 mixed at a ratio of 1:1) cultures. After 45 min of ripening, the milk was coagulated using double-strength chymosin per the manufacturer instructions (Chy-Max; Chr. Hansen). The milk coagulated in $40 \mathrm{~min}$, and the curd was cut into $1-\mathrm{cm}^{3}$ cubes using cheese knives and allowed to settle for $5 \mathrm{~min}$. The curd was stirred for $20 \mathrm{~min}$ at $40^{\circ} \mathrm{C}$. The whey was drained and curd cubes were transferred to a cheesecloth. Curd pieces were wrapped in cheesecloth in small portions $(\sim 250 \mathrm{~g})$ and pressed for 90 min. Young cheese pieces were brined in $10 \%$ (wt/vol) brine solution overnight at $4^{\circ} \mathrm{C}$. Then, the cheese pieces were vacuum-packaged and stored at $4^{\circ} \mathrm{C}$. Cheeses were sampled at $0,7,14$, and $21 \mathrm{~d}$ of storage at $4^{\circ} \mathrm{C}$.

\section{Bacterial Enumeration}

The LAB in cheeses were enumerated according to Ayyash and Shah (2011). An aliquot of grated cheese $(10 \mathrm{~g})$ was taken from the shredded cheese block, placed in a stomacher bag, and blended with $90 \mathrm{~mL}$ of sterile distilled water using a Stomacher-400 laboratory blender (Seward Medical, London, UK). Appropriate serial dilutions were made using $0.1 \%$ (wt/vol) peptone, and LAB populations were counted using MRS agar (Oxoid). Inoculated plates in duplicate were in- 
cubated anaerobically at $37^{\circ} \mathrm{C}$ for $48 \mathrm{~h}$ using anaerobic jar system (Don Whitley Scientific Ltd., Shipley, UK).

\section{Proteolysis Assessment}

Water-soluble extracts (WSE) were prepared according to Kuchroo and Fox (1982) by homogenizing a 50-g grated subsample of cheese with $100 \mathrm{~mL}$ of deionizeddistilled (dd) water. The slurries were centrifuged at $8,000 \times g$ for $15 \mathrm{~min}$ at $4^{\circ} \mathrm{C}$.

$\boldsymbol{O P A}$. The OPA of WSE was determined as described by Ayyash et al. (2012). Briefly, $50 \mu \mathrm{L}$ of WSE was placed into a $1.5-\mathrm{mL}$ cuvette and mixed with $1 \mathrm{~mL}$ of OPA reagent prepared in a $50-\mathrm{mL}$ volumetric flask as follows: $25 \mathrm{~mL}$ of $100 \mathrm{~m} M$ disodium tetraborate (Merck Pty Ltd., Kenilworth, NJ), $2.5 \mathrm{~mL}$ of $20 \%$ (wt/wt) SDS (Merck Pty Ltd.), $40 \mathrm{mg}$ of OPA dissolved in $1 \mathrm{~mL}$ of methanol (Sigma-Aldrich, St. Louis, MO), and 100 $\mu \mathrm{L}$ of $\beta$-mercaptoethanol (Sigma-Aldrich). The volume was completed to $50 \mathrm{~mL}$ with addition of Milli-Q water. The cuvette was inverted twice and then incubated for 2 min at room temperature. Absorbance was measured at $340 \mathrm{~nm}$ using a UV-Vis spectrophotometer (Jenway 6300, Jenway, Stone, UK).

$\boldsymbol{T F A} \boldsymbol{A}$. The TFAA of WSE was assayed as described by Ayyash et al. (2012). Briefly, an aliquot $(100 \mu \mathrm{L})$ was placed in a glass tube and diluted with $1 \mathrm{~mL}$ of Milli-Q water. Two milliliters of Cd-ninhydrin reagent $(0.8 \mathrm{~g}$ of ninhydrin was dissolved in a mixture of 10 $\mathrm{mL}$ of glacial acetic acid (100\%) and $80 \mathrm{~mL}$ of ethanol (99.5\%) followed addition of $1 \mathrm{~g}$ of $\mathrm{CdCl}_{2}$ dissolved in 1 $\mathrm{mL}$ of Milli-Q water. The mixture was heated at $84^{\circ} \mathrm{C}$ for $5 \mathrm{~min}$ and then cooled at room temperature; then, absorbance was measured at $507 \mathrm{~nm}$ using a UV-Vis spectrophotometer (Jenway 6300, Jenway). All chemicals were purchased from Sigma-Aldrich.

\section{a-Amylase Inhibition}

Before the assay, stored WSE was vortexed for $1 \mathrm{~min}$ followed by centrifugation at $10,000 \times g$ for $5 \mathrm{~min}$. The $\alpha$-amylase inhibition assay was carried out according to the method described by Kim et al. (2004) with minor modifications. Briefly, $100 \mu \mathrm{L}$ of $\alpha$-amylase from human salivary (1.0 unit/mL, Sigma-Aldrich) was premixed with $100 \mu \mathrm{L}$ of WSE. After incubation at $37^{\circ} \mathrm{C}$ for 5 min, $250 \mu \mathrm{L}$ of $1 \%$ starch was added as a substrate in PBS ( $\mathrm{pH}$ 6.8) to start the reaction. The reaction was performed at $37^{\circ} \mathrm{C}$ for $5 \mathrm{~min}$ and terminated by the addition of $200 \mu \mathrm{L}$ of DNS reagent (1\% 3,5-dinitrosalicylic acid and $12 \%$ sodium potassium tartrate in $0.4 \mathrm{M}$ $\mathrm{NaOH})$. The reaction mixture was heated for $15 \mathrm{~min}$ at $100^{\circ} \mathrm{C}$ and diluted with $2 \mathrm{~mL}$ of distilled water in an ice bath. $\alpha$-Amylase activity was determined by measuring absorbance at $540 \mathrm{~nm}$.

\section{a-Glucosidase Inhibition}

Before the assay, stored WSE were vortexed for 1 min followed by centrifugation at $10,000 \times g$ for $5 \mathrm{~min}$. The $\alpha$-glucosidase inhibition assay was carried out according to the method detailed in Kim et al. (2004) with some modifications. $\alpha$-Glucosidase $(1 \mathrm{unit} / \mathrm{mL}$ ) was dissolved in $100 \mu \mathrm{L}$ of $0.1 \mathrm{M}$ potassium phosphate buffer $(\mathrm{pH}$ 6.8) and mixed with $50 \mu \mathrm{L}$ of WSE. After incubation at $37^{\circ} \mathrm{C}$ for $10 \mathrm{~min}, 5 \mathrm{~m} M p$-nitrophenol from $p$-nitrophenyl $\alpha$-D-glucopyranoside (pNPG; $50 \mu \mathrm{L}$ ) was added as substrate. The enzymatic reaction was performed at $37^{\circ} \mathrm{C}$ for $30 \mathrm{~min}$ and stopped by the addition of $1 \mathrm{~mL}$ of $0.1 \mathrm{M} \mathrm{Na}_{2} \mathrm{CO}_{3}$. $\alpha$-Glucosidase activity was determined by measuring the release of $p$-nitrophenol from $\mathrm{pNPG}$ at $400 \mathrm{~nm}$. Solution without sample was used as a control, and solution without substrate was used as a blank. The inhibition percentage was calculated as follows (where Abs = absorbance):

$$
\text { Inhibition } \%=\left(1-\frac{\text { Abs sample }- \text { Abs blank }}{\text { Abs control }}\right) \times 100 \text {. }
$$

\section{Antioxidant Activity}

Before the antioxidant assays, stored WSE were vortexed for $1 \mathrm{~min}$ followed by centrifugation at $10,000 \times$ $g$ for 5 min.

Radical-Scavenging Rate by DPPH. Radicalscavenging activity by DPPH was assayed according to Elfahri et al. (2016). Briefly, $800 \mu \mathrm{L}$ of DPPH reagent (0.1 mM DPPH dissolved in 95\% methanol) was added to $200 \mu \mathrm{L}$ of WSE in glass test tubes. The samples were shaken vigorously and incubated in the dark at room temperature for $30 \mathrm{~min}$. Methanol was used as a blank. The absorbance of the incubated samples was measured at $517 \mathrm{~nm}$. The radical-scavenging activity (\%) was expressed as follows:

$$
\text { Scavenging rate }(\%)=\left(1-\frac{\text { Abs sample }}{\text { Abs blank }}\right) \times 100 \text {. }
$$

Radical-Scavenging Rate by ABTS. Radicalscavenging rate by ABTS radical $\left(\mathbf{A B T S}^{\bullet+}\right)$ was assayed according to Sah et al. (2014). A stock solution of ABTS was prepared by mixing stock solutions of 7.4 $\mathrm{m} M$ ABTS aqueous solution and $2.6 \mathrm{~m} M$ potassium persulfate aqueous solution in equal quantities (molar ratio $=1: 0.35)$ and allowing them to react for $12 \mathrm{~h}$ in 
the dark at room temperature. Fresh ABTS reagent was prepared by mixing $1 \mathrm{~mL}$ of $\mathrm{ABTS}^{\bullet+}$ solution with 50 to $60 \mathrm{~mL}$ of buffered methanol to obtain an absorbance of $0.70 \pm 0.02$ at $734 \mathrm{~nm}$ after equilibration at $30^{\circ} \mathrm{C}$. Twenty microliters of properly diluted WSE in dd-water was added to $2 \mathrm{~mL}$ of ABTS reagent and incubated at $30^{\circ} \mathrm{C}$ for $6 \mathrm{~min}$. The absorbance of the mixture was measured at $734 \mathrm{~nm}$. Similarly, $20 \mu \mathrm{L}$ of dd-water was used instead of the sample for the blank. Radical-scavenging activity was calculated as follows:

Scavenging $\operatorname{rate}(\%)=\left(\frac{\text { Abs blank }- \text { Abs sample }}{\text { Abs blank }}\right) \times 100$.

\section{ACE Inhibition}

Before the ACE inhibition assays, stored WSE was vortexed for $1 \mathrm{~min}$ followed by centrifugation at 10,000 $\times g$ for $5 \mathrm{~min}$. The ACE inhibition of WSE was assayed according to methods detailed in Ayyash and Shah (2011). Briefly, $5 \mathrm{~mL}$ of WSE was freeze-dried and dissolved in $1 \mathrm{~mL}$ of Tris buffer $(50 \mathrm{mM}, \mathrm{pH} 8.3)$ containing $300 \mathrm{~m} M \mathrm{NaCl}$. An ACE enzyme (from rabbit lung) and hippuryl-histidyl-leucine (HHL) purchased from Sigma-Aldrich was prepared in Tris buffer. The assay consisted of $100 \mu \mathrm{L}$ of $3.0 \mathrm{~m} M \mathrm{HHL}, 100 \mu \mathrm{L}$ of ACE enzyme $(1.25 \mathrm{mU} / \mathrm{mL})$, and $100 \mu \mathrm{L}$ of dissolved WSE sample. The mixture was placed in a glass tube and then incubated for $30 \mathrm{~min}$ at $37^{\circ} \mathrm{C}$ in a water bath without mixing and then for an additional 30 min after mixing. Glacial acetic acid $(200 \mu \mathrm{L})$ was added to stop ACE enzyme activity. The mixture was kept at $-20^{\circ} \mathrm{C}$ to be analyzed later using HPLC. The resulting hippuric acid (HA) from the previous reaction was determined using HPLC. An external standard curve was prepared to quantify the HA in assay samples. An aliquot (20 $\mu \mathrm{L}$ ) of the mixture was injected into the HPLC system (ThermoFisher Scientific, Waltham, MA). The system was fitted with a reverse-phase column (C18, $250 \mathrm{~mm}$ long $\times 4.6 \mathrm{~mm}$ in diameter, 5 - $\mu \mathrm{m}$ diameter of the HPLC column particles inside with a guard column $(\mathrm{C} 18,4 \times 3.0 \mathrm{~mm})$. The separation was conducted at room temperature $\left(\sim 22^{\circ} \mathrm{C}\right)$ at a flow rate of $0.8 \mathrm{~mL} /$ min. The mobile phase was an isocratic system consisting of $12.5 \%$ ( $\mathrm{vol} / \mathrm{vol}$ ) acetonitrile (Sigma-Aldrich) in Milli-Q water, and the $\mathrm{pH}$ was adjusted to $\mathrm{pH} 3.0$ using glacial acetic acid (Sigma-Aldrich). The detection device was a UV-Vis detector set at $228 \mathrm{~nm}$. The control reaction mixture contained $100 \mu \mathrm{L}$ of buffer instead of the assay sample; the control was expected to liberate the maximum amount of HA from the substrate due to uninhibited ACE activity. The percentage inhibition of enzyme activity was calculated as follows:
ACE inhibition $(\%)=\left(\frac{\text { HA control }- \text { HA sample }}{\text { HA control }}\right) \times 100$.

\section{Antiproliferative Activities}

Before the assay, WSE were filtered through Macrosep Advance Spin Filter $3 \mathrm{kD}$ (Pall Corporation, Port Washington, NY). Filtrates were assayed against Caco2 and MCF-7 carcinoma cell lines according to method details by Elfahri et al. (2016). Cell lines used for the cell cytotoxicity assay included a colon cancer cell line (Caco-2; provided by Dr. Carine Platat, Nutrition and Health Department, United Arab Emirates University) and a breast cancer cell line MCF-7 (Faculty of Medicine and Health Sciences, United Arab Emirates University). Cells were grown in humidified incubator $\left(37^{\circ} \mathrm{C}\right.$ and $\left.5 \% \mathrm{CO}_{2}\right)$ in Dulbecco's modified Eagle's medium (Gibco, Invitrogen, Carlsbad, CA) supplemented with $10 \%$ heat-inactivated bovine serum (FBS) and $1 \%$ penicillin and streptomycin (Invitrogen). Cell lines were initially passed and counted in hemocytometer before the seeding. Cells were seeded at $1 \times 10^{3}$ concentration in the 96-well plate and incubated in appropriate medium overnight. For the treatment, $25 \mu \mathrm{L}$ of filtered WSE was added to each well and incubated for $72 \mathrm{~h}$ at $37^{\circ} \mathrm{C}$ and $5 \% \mathrm{CO}_{2}$. Cells without WSE were used as a control. Afterward, $20 \mu \mathrm{L}$ of warmed Abcam Cell Cytotoxicity Assay Kit (ab112118, Abcam, Cambridge, MA) was added and incubated at $37^{\circ} \mathrm{C}$ for at least 5 h. The absorbance was measured at 570 and $605 \mathrm{~nm}$ according to the kit manufacturer's protocol. The ratio of optical density (OD) at $570 \mathrm{~nm}$ to OD at $605 \mathrm{~nm}$ was used to determine the inhibition of the cell growth in each well. The proliferative inhibition was calculated as follows:

$$
\begin{gathered}
\text { Proliferative inhibition }(\%)= \\
[1-\text { Rsample }- \text { Ro }) /(\text { Rctrl }- \text { Ro })] \times 100,
\end{gathered}
$$

where Rsample is the absorbance ratio of $\mathrm{OD}_{570} / \mathrm{OD}_{605}$ in the presence of the WSE; Rctrl is the absorbance ratio of $\mathrm{OD}_{570} / \mathrm{OD}_{605}$ in the absence of the WSE (vehicle control); and Ro is the averaged background (non-cell control) absorbance ratio of $\mathrm{OD}_{570} / \mathrm{OD}_{605}$.

\section{Statistical Analysis}

Cheese making was carried out in duplicate, each experimental unit was subsampled in duplicate, and each subsample was assayed in duplicate. Thus, result values are mean \pm standard deviation (SD) of $n=8$. Two-way ANOVA was carried out to investigate the effect of cul- 
ture type and storage period on cheese parameters $(P<$ $0.05)$. Means comparisons at same storage period was performed using Tukey's test $(P<0.05)$. All statistical analyses were carried out using Minitab 17.0 software (Minitab Inc., State College, PA).

\section{RESULTS AND DISCUSSION}

\section{LAB Enumeration and Proteolysis Assessment}

Bacterial count and OPA and TFAA assay results (as assessment of proteolysis) are presented in Figure 1 (panels A, B, and C, respectively). The populations of LAB did not differ significantly between the cheeses produced by different starter cultures in the same storage period. The number of LAB remained $>7.0 \log _{10}$ $\mathrm{cfu} / \mathrm{g}$ in all cheeses during $21 \mathrm{~d}$ of storage at $4^{\circ} \mathrm{C}$ (Figure 1A). The proteolysis parameters OPA and TFAA increased significantly $(P<0.05)$ with prolonged storage of all cheeses (Figure 1B and 1C). Levels of OPA and TFAA in all cheeses produced with $\mathrm{MEPS}^{+}$and $\mathrm{CEPS}^{+}$were significantly higher $(P<0.05)$ than those of cheeses produced with EPS $^{-}$cultures. At the end of storage, the OPA level in $\mathrm{CEPS}^{+}$cheeses were the same as that in $\mathrm{MEPS}^{+}$cheeses, and TFAA values in $\mathrm{CEPS}^{+}$cheeses were close to those in $\mathrm{MEPS}^{+}$cheeses. The $\mathrm{OD}_{340 \mathrm{~nm}}$ of OPA in $\mathrm{CEPS}^{+}$cheese increased by 1.430 compared with 1.230 in $\mathrm{MEPS}^{+}$cheeses at the end of storage period.

The greater values of OPA and TFAA, as indicators for secondary and advanced proteolysis (McSweeney and Fox, 1997), respectively, in cheeses made with EPS ${ }^{+}$ cultures may be due to accelerated primary proteolysis along with high proteolytic activities of $\mathrm{EPS}^{+}$cultures. Similarly, Oluk et al. (2014) reported that TFAA were higher in Tulum cheese made with an $\mathrm{EPS}^{+}$culture. Furthermore, proteolytic activities of $\mathrm{CEPS}^{+}$cultures isolated from camel milk were comparable to that produced with $\mathrm{MEPS}^{+}$culture. Therefore, these cultures may be used in the production of different dairy products such as cheese or yogurt produced from camel milk to enhance their texture.

\section{$\alpha$-Glucosidase and $\alpha$-Amylase Inhibition}

The inhibitory effects of all cheeses on $\alpha$-glucosidase or $\alpha$-amylase activity during $21 \mathrm{~d}$ of storage are presented in Figure 2A and B, respectively. The percentage of $\alpha$-glucosidase inhibition ranged from $>45 \%$ at $0 \mathrm{~d}$ to $\sim 55 \%$ at $21 \mathrm{~d}$ of storage. Although $\alpha$-glucosidase inhibition increased $(P<0.05)$ during storage (Figure 2A), ANOVA showed that $\alpha$-glucosidase inhibition differed numerically but not significantly $(P>0.05)$ between experimental cheeses. On the other hand, $\alpha$-amylase inhibition was significantly higher $(P<0.05)$ in cheeses made with $\mathrm{EPS}^{+}$cultures than with $\mathrm{EPS}^{-}$cultures during storage. It was interesting to note that cheeses made with $\mathrm{CEPS}^{+}$culture showed higher $\alpha$-amylase inhibition compared with $\mathrm{MEPS}^{+}$at d 21 of storage (Figure 2B). The $\alpha$-amylase inhibition in $\mathrm{CEPS}^{+}$cheese remained $>30 \%$ during $14 \mathrm{~d}$ of storage followed by a rapid increase to $>50 \%$ at $21 \mathrm{~d}$ of storage (Figure $2 \mathrm{~B}$ ).

The inhibition of $\alpha$-amylase and $\alpha$-glucosidase is considered an effective approach to control diabetes via diminishing carbohydrate hydrolysis (Donkor et al., 2012). The general inhibition of both $\alpha$-amylase and
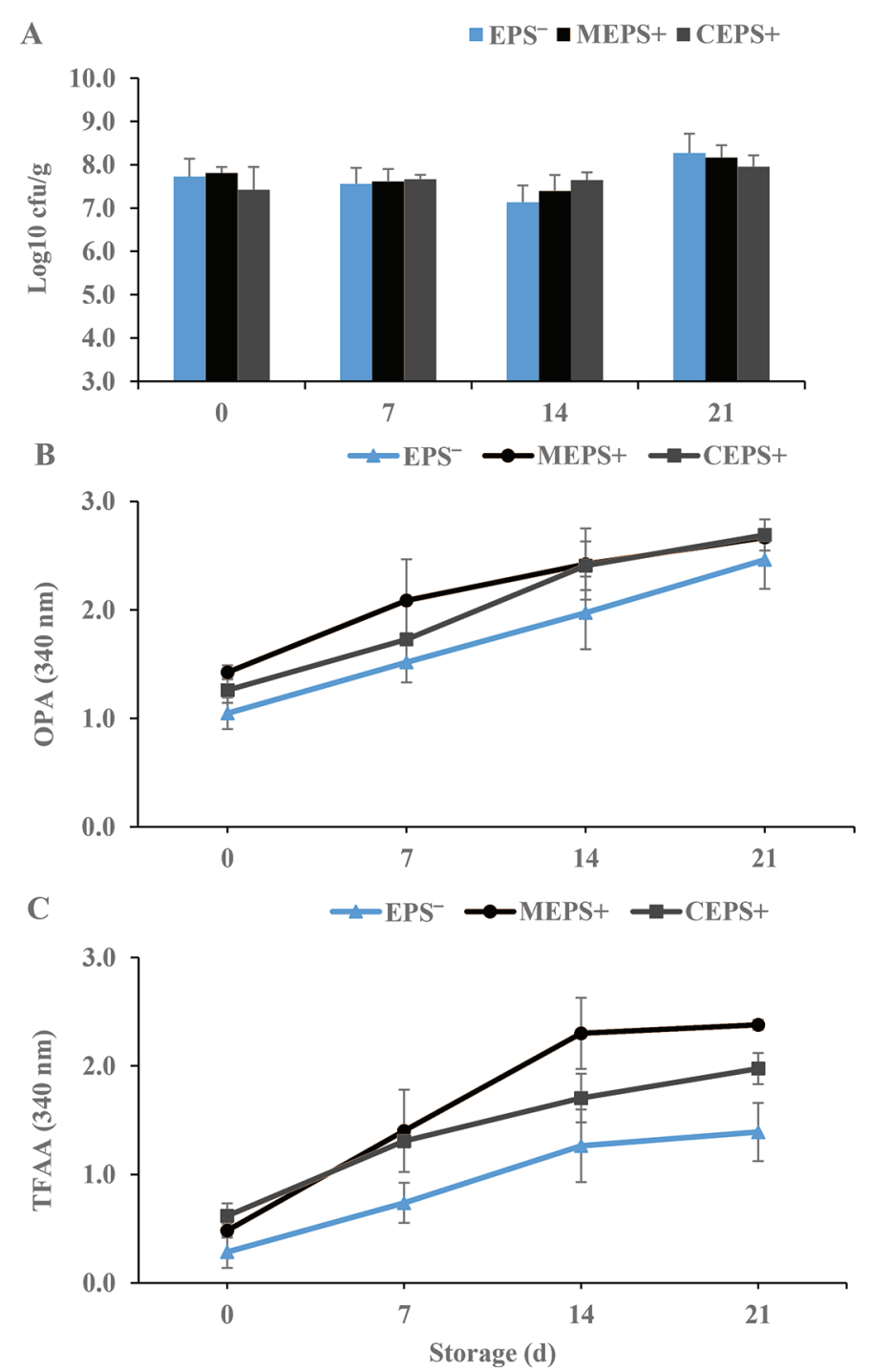

Figure 1. (A) Lactic acid bacteria count, (B) o-phthalaldehyde (OPA), and (C) total free AA (TFAA) of 3 experimental cheeses during $21 \mathrm{~d}$ of storage. $\mathrm{EPS}^{-}=$non-exopolysaccharide (EPS)-producing culture; $\mathrm{MEPS}^{+}=$commercial EPS-producing culture; $\mathrm{CEPS}^{+}=$ EPS-producing Lactobacillus plantarum isolated from camel milk. Values are mean $\pm \mathrm{SD}(\mathrm{n}=8)$. Color version available online. 
A

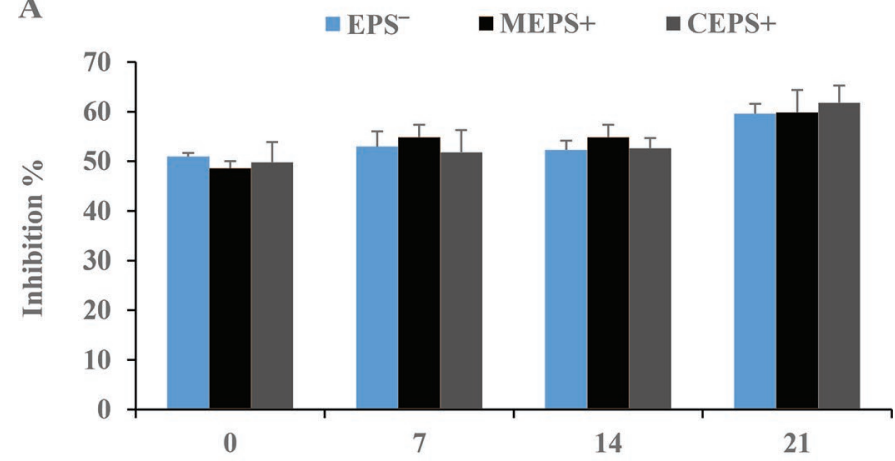

B

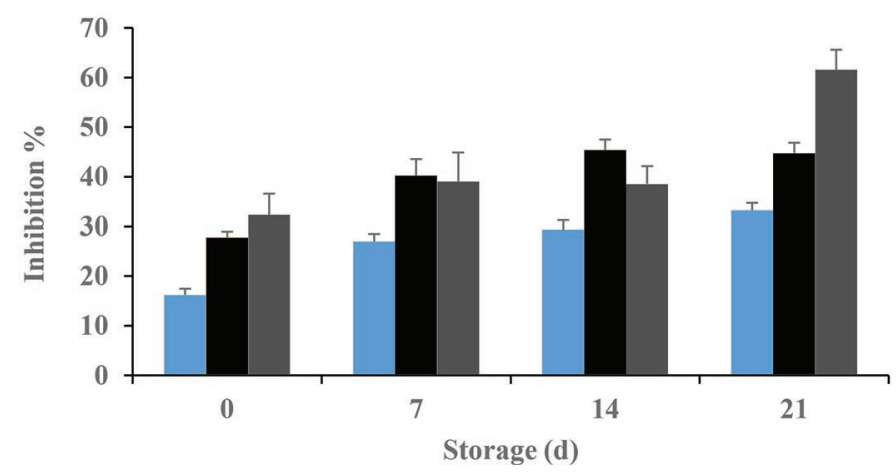

Figure 2. (A) $\alpha$-Glucosidase inhibition and (B) $\alpha$-amylase inhibition of 3 experimental cheeses during $21 \mathrm{~d}$ of storage. $\mathrm{EPS}^{-}=$nonexopolysaccharide (EPS)-producing culture; $\mathrm{MEPS}^{+}=$commercial EPS-producing culture; CEPS $^{+}=$EPS-producing Lactobacillus plantarum isolated from camel milk. Values are mean $\pm \mathrm{SD}(\mathrm{n}=8)$. Color version available online.

$\alpha$-glucosidase enzymes may be attributed to (1) bioactive peptides, particularly small peptides produced by the action of proteolytic enzymes secreted by cheese cultures (Gomes da Cruz et al., 2009), and (2) the bioactivity of EPS produced by cheese cultures, especially $\mathrm{EPS}^{+}$cultures (Aluko, 2012). Several researchers have reported that small peptides have shown antidiabetic activity in egg white, soybean, legumes, and fish (Vadivel et al., 2011; Yu et al., 2011, 2012). Nehir El et al. (2015) reported that small peptides in goat milk and kefir products exhibited inhibition against $\alpha$-amylase and $\alpha$-glucosidase. The proteolysis assessment (OPA and TFAA assays) in the present study showed that the experimental cheeses produced bioactive peptides. This reveals the consistency between proteolytic activities (Figure 1) and $\alpha$-amylase and $\alpha$-glucosidase inhibition results. In the current study, we assumed that the EPS produced by $\mathrm{EPS}^{+}$cultures contributed to $\alpha$-amylase and $\alpha$-glucosidase inhibition, which in turn may explain the higher percentages of $\alpha$-amylase inhibition in cheeses made with $\mathrm{EPS}^{+}$cultures compared with $\mathrm{EPS}^{-}$ culture. Our result demonstrated that a culture isolated from camel milk $\left(\mathrm{CEPS}^{+}\right)$had comparable proteolytic activity to the $\mathrm{MEPS}^{+}$culture, which may produce antidiabetic peptides (Figure 2). The mechanisms of physiological activities of EPS remain unclear and this requires further investigation (Badel et al., 2011). To the best of our knowledge, EPS as prebiotics can promote human health (Ruas-Madiedo et al., 2002).

\section{Antioxidant Activity (DPPH and ABTS)}

The radical-scavenging rates (\%), measured by DPPH and ABTS assays, of cheeses during $21 \mathrm{~d}$ of storage are presented in Figure 3A and 3B). Scavenging rates of experimental cheeses made with $\mathrm{EPS}^{+}$cultures were higher $(P<0.05)$ than that of $\mathrm{EPS}^{-}$cultures (Figure $3 \mathrm{~A}$ and $3 \mathrm{~B}$ ). Cheese made with $\mathrm{CEPS}^{+}$culture exhibited comparable antioxidant activity to that made with MEPS $^{+}$culture. Scavenging rates increased significantly $(P<0.05)$ with prolonged storage (Figure 3A and 3B). After $14 \mathrm{~d}$ of storage, the scavenging rate by ABTS in $\mathrm{CEPS}^{+}$cheese increased $>60 \%$ (Figure $3 \mathrm{~B}$ ) and $>20 \%$ by DPPH (Figure 3A). This implies that antioxidant activities in $\mathrm{CEPS}^{+}$increased during storage.

Bioactive compounds in foods, especially fermented dairy products, play a crucial role in elevating the effect of reactive oxygen species such as superoxide $\left(\mathrm{O}_{2}{ }^{\bullet}\right.$, $\left.{ }^{\bullet} \mathrm{OOH}\right)$, hydroxyl $\left({ }^{\bullet} \mathrm{OH}\right)$, and peroxyl $\left(\mathrm{ROO}^{\bullet}\right)$ radicals formed by oxidatively stressed cells (Benbrook, 2005). These bioactive compounds, especially protein-derived peptides, possess the ability to donate electrons to neutralize free radicals. Therefore, the presence of several amino acid residues in the peptide chain can enhance antioxidant properties (Aluko, 2012). The DPPH and ABTS results of the present study may be attributed primarily to bioactive peptides resulting from the proteolytic action of cheese cultures. The higher DPPH and ABTS of cheeses made with $\mathrm{EPS}^{+}$cultures may also be attributed to bioactive EPS produced by these cultures. It is noteworthy that scavenging rates of $\mathrm{DPPH}$ were lower than those of ABTS. This result may be attributed to the nature of the antioxidant test. Floegel et al. (2011) reported lower DPPH scavenging rates than ABTS for several US food products.

\section{ACE Inhibition}

Figure 4 displays the ACE inhibitory activities (\%) of the 3 experimental cheeses during $21 \mathrm{~d}$ of storage. Throughout storage, the experimental cheeses made with $\mathrm{EPS}^{+}$cultures exhibited higher $(P<0.05) \mathrm{ACE}$ inhibitory activity compared with those made with $\mathrm{EPS}^{-}$. Low-fat akawi cheese made with $\mathrm{CEPS}^{+}$demonstrated comparable ACE inhibitory activity to that of 
A

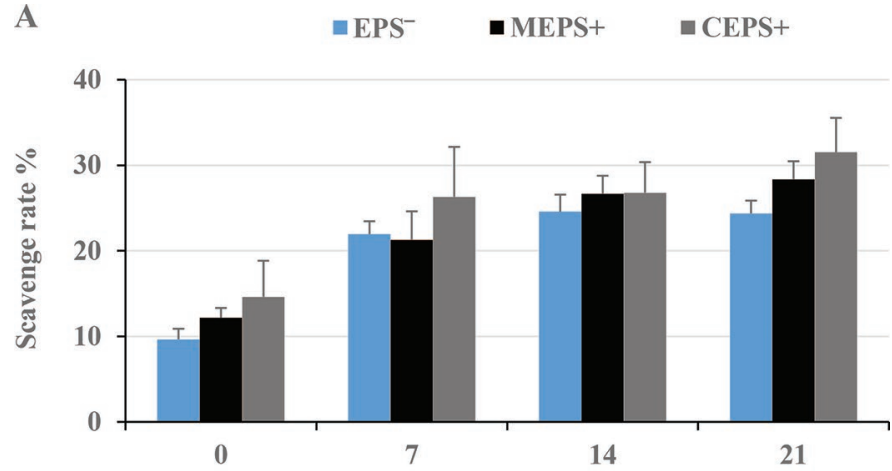

B

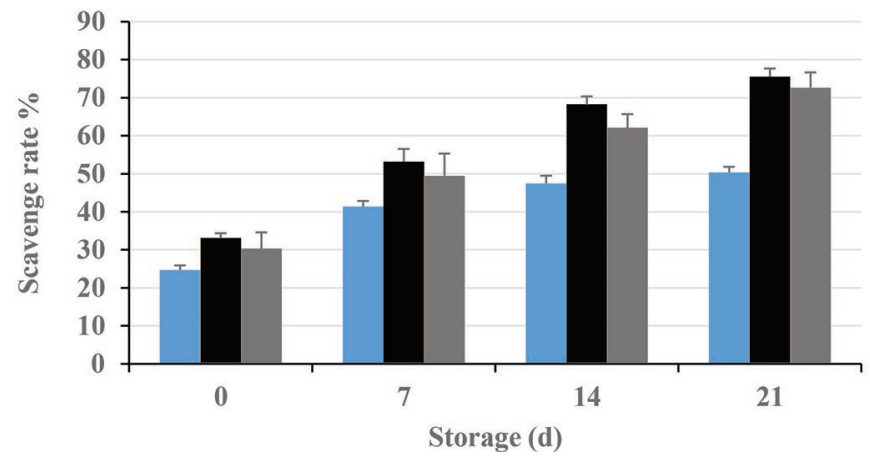

Figure 3. Antioxidant activity by (A) 1,1-diphenyl-2-picrylhydrazyl (DPPH) and (B) 2,2'-azino-bis(3-ethylbenzo-thiazoline-6-sulfonic acid) (ABTS) of 3 experimental cheeses during $21 \mathrm{~d}$ of storage. $\mathrm{EPS}^{-}=$ non-exopolysaccharide (EPS)-producing culture; $\mathrm{MEPS}^{+}=$commercial EPS-producing culture; $\mathrm{CEPS}^{+}=$EPS-producing Lactobacillus plantarum isolated from camel milk. Values are mean $\pm \mathrm{SD}(\mathrm{n}=8)$. Color version available online.

MEPS $^{+}$. The CEPS ${ }^{+}$cheese had ACE inhibitory activity $>70 \%$ after $7 \mathrm{~d}$ of storage (Figure $4 \mathrm{~A}$ ).

Inhibition of $\mathrm{ACE}$ activity is an in vitro indicator of the antihypertensive properties of fermented dairy products (Gobbetti et al., 2004). The higher ACE inhibitory activity of the cheese made with $\mathrm{EPS}^{+}$cultures may be attributed to the presence of EPS in these cheeses. In general, the results of ACE inhibition in the current study are consistent with results of Ayyash et al. (2012). It has been reported that ACE inhibition may be primarily attributed to the bioactivity of casein-derived peptides that may be produced by proteolytic enzymes from added cultures (Ayyash et al., 2012). Ruas-Madiedo et al. (2002) reported that EPS promotes human health as a prebiotic or due to antitumor, antiulcer, immunomodulating, or cholesterollowering activities. Therefore, we postulate that EPS in low-fat akawi cheeses may have contributed to the ACE inhibitory activities. Further work is needed to investigate the mechanism of ACE inhibition by EPS. The antiproliferative activity of bioactive peptides, especially small peptides, in dairy products has been extensively reported (Clare and Swaisgood, 2000; Hoerr and Bostwick, 2000).

\section{Antiproliferative Activities}

The antiproliferative activities of 3 cheeses against human epithelial carcinoma (Caco-2) and breast cancer (MCF-7) cell lines are shown in Figures 5A and $5 \mathrm{~B}$, respectively. All cheeses exhibited antiproliferative activity against Caco-2 and MCF-7 cell lines. The antiproliferative activities against Caco-2 (Figure 5A) increased significantly $(P<0.05)$ throughout the storage period. Antiproliferation activity of $\mathrm{CEPS}^{+}$cheese increased from 38 to $48 \%$ during $7 \mathrm{~d}$ of storage and maintained antiproliferation above $45 \%$ with prolonged storage (Figure 5A). It is noteworthy that proliferation inhibition against MCF-7 was higher than that against Caco-2 (Figure 5A and 5B). Figures 5A and 5B demonstrate that antiproliferative activities of WSE extracted from cheeses made with $\mathrm{CEPS}^{+}$cultures were comparable to those in cheese from $\mathrm{MEPS}^{+}$. The EPS ${ }^{-}$culture had similar antiproliferative activities to $\mathrm{MEPS}^{+}$and $\mathrm{CEPS}^{+}$cultures (Figure 5A and 5B).

The antiproliferation activities of milk peptides have been reported by Park (2009). Several hypotheses have been proposed explaining the mechanism(s) of the antiproliferative activities of milk peptides. Competition between peptides and cancer growth factors for cancer cell-membrane receptors is one such hypothesis. Another hypothesis claims that released peptides have specific cytotoxicity on cancer cells, which induces apoptosis (Picot et al., 2006; Pessione and Cirrincione, 2016). In the current study, the maximum molecular size in

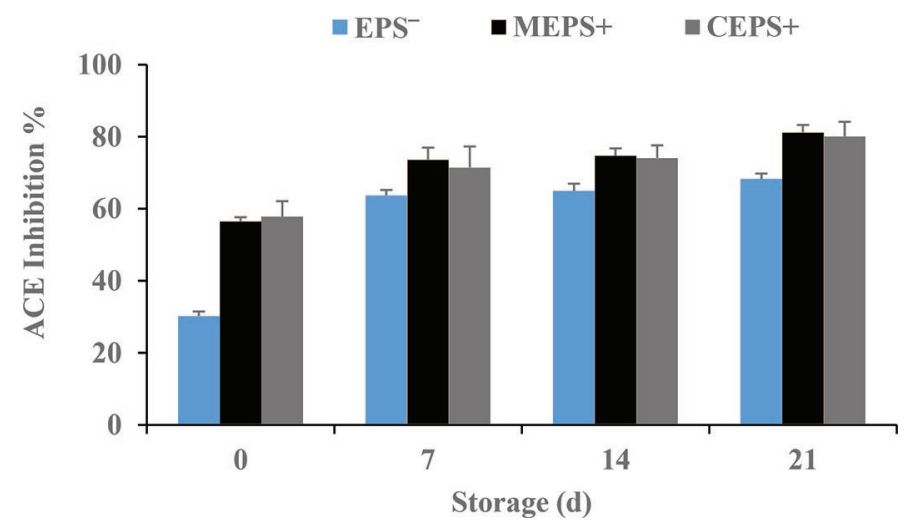

Figure 4. Angiotensin-converting enzyme (ACE) inhibition of 3 experimental cheeses during $21 \mathrm{~d}$ of storage. $\mathrm{EPS}^{-}=$non-exopolysaccharide (EPS)-producing culture; $\mathrm{MEPS}^{+}=$commercial EPS-producing culture; CEPS $^{+}=$EPS-producing Lactobacillus plantarum isolated from camel milk. Values are mean $\pm \mathrm{SD}(\mathrm{n}=8)$. Color version available online. 
A

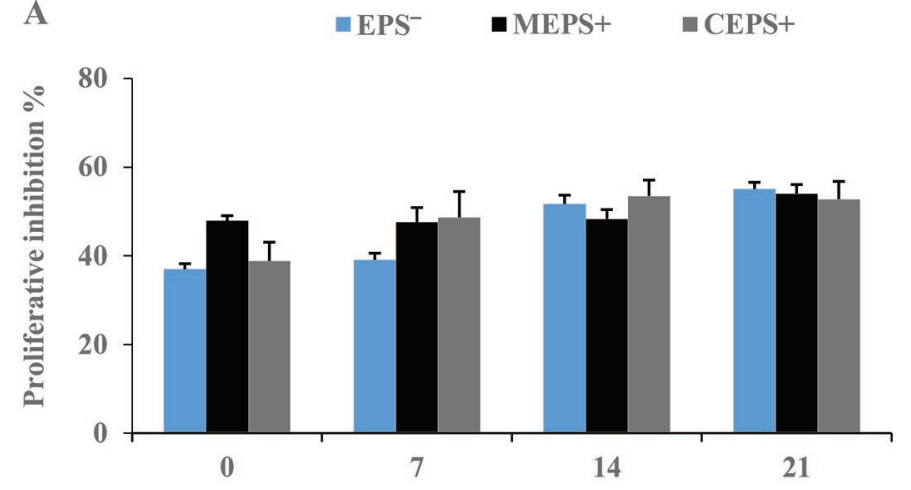

B

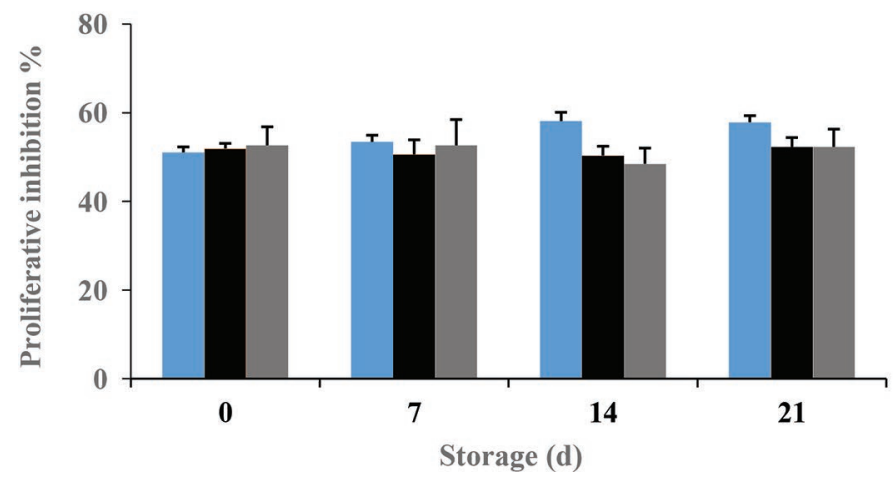

Figure 5. Antiproliferative activity against (A) Caco-2 and (B) MCF-7 cell lines of 3 experimental cheeses during $21 \mathrm{~d}$ of storage. $\mathrm{EPS}^{-}=$non-exopolysaccharide (EPS)-producing culture; $\mathrm{MEPS}^{+}$ $=$ commercial EPS-producing culture; $\mathrm{CEPS}^{+}=$EPS-producing Lactobacillus plantarum isolated from camel milk. Values are mean \pm $\mathrm{SD}(\mathrm{n}=8)$. Color version available online.

the filtered WSE was $\leq 3,000$ Da. Gandhi and Shah (2016) reported antiproliferative activities for akawi cheese against Caco-2 cells. Although those authors did not filter the WSE to control the molecular size of the extract, the antiproliferative percentages reported by Gandhi and Shah (2016) agree with the results from the current study.

\section{CONCLUSIONS}

Newly isolated Lb. plantarum KX881772 and KX881779 strains from camel milk demonstrated promising probiotic characteristics in low-fat cheese compared with commercial cultures. Moreover, low-fat akawi cheese produced with $\mathrm{CEPS}^{+}$cultures exhibited similar and, in some instances, more pronounced (e.g., $\alpha$-amylase inhibition) health-promoting benefits than the commercial starter culture $\left(\mathrm{MEPS}^{+}\right)$. Lactobacillus plantarum cultures showed similar performance to commercially available cultures and deserve further consideration.

\section{ACKNOWLEDGMENTS}

The authors are grateful to United Arab Emirates University (UAEU) for funding this project via Grant No. G00001612. The authors are also thankful to ChrHansen Holding A/S (Dubai Branch) for providing the commercial $\mathrm{EPS}^{+}$culture.

\section{REFERENCES}

Abd El-Salam, M. H., and E. Alichanidis. 2004. Cheese varieties ripened in brine. Pages 227-249 in Cheese: Chemistry, Physics and Microbiology. Vol. 2. P. F. Fox, P. L. McSweeney, T. M. Cogan, and P. G. Timothy, ed. Academic Press, San Diego, CA.

Abushelaibi, A., S. Al-Mahadin, K. El-Tarabily, N. P. Shah, and M. Ayyash. 2017. Characterization of potential probiotic lactic acid bacteria isolated from camel milk. Lebensm. Wiss. Technol. 79:316-325.

Aluko, R. E. 2012. Functional Foods and Nutraceuticals. Springer New York, New York, NY.

Ayyash, M. M., and N. P. Shah. 2011. Proteolysis of low-moisture Mozzarella cheese as affected by substitution of $\mathrm{NaCl}$ with $\mathrm{KCl}$. J. Dairy Sci. 94:3769-3777.

Ayyash, M. M., F. Sherkat, and N. P. Shah. 2012. The effect of $\mathrm{NaCl}$ substitution with $\mathrm{KCl}$ on Akawi cheese: Chemical composition, proteolysis, angiotensin-converting enzyme-inhibitory activity, probiotic survival, texture profile, and sensory properties. J. Dairy Sci. 95:4747-4759.

Badel, S., T. Bernardi, and P. Michaud. 2011. New perspectives for lactobacilli exopolysaccharides. Biotechnol. Adv. 29:54-66.

Benbrook, C. M. 2005. Elevating antioxidant levels in food through organic farming and food processing. Organic Center, State of Science Review, January. https://www.organic-center.org/reportfiles/ Antioxidant_SSR.pdf.

Caggianiello, G., M. Kleerebezem, and G. Spano. 2016. Exopolysaccharides produced by lactic acid bacteria: From health-promoting benefits to stress tolerance mechanisms. Appl. Microbiol. Biotechnol. 100:3877-3886.

Clare, D. A., and H. E. Swaisgood. 2000. Bioactive milk peptides: A prospectus. J. Dairy Sci. 83:1187-1195.

Costa, N. E., J. A. Hannon, T. P. Guinee, M. A. E. Auty, P. L. H. McSweeney, and T. P. Beresford. 2010. Effect of exopolysaccharide produced by isogenic strains of Lactococcus lactis on half-fat Cheddar cheese. J. Dairy Sci. 93:3469-3486.

Dilna, S. V., H. Surya, R. G. Aswathy, K. K. Varsha, D. N. Sakthikumar, A. Pandey, and K. M. Nampoothiri. 2015. Characterization of an exopolysaccharide with potential health-benefit properties from a probiotic Lactobacillus plantarum RJF4. Lebensm. Wiss. Technol. 64:1179-1186.

Donkor, O. N., L. Stojanovska, P. Ginn, J. Ashton, and T. Vasiljevic. 2012. Germinated grain - Sources of bioactive compounds. Food Chem. 135:950-959.

Duboc, P., and B. Mollet. 2001. Applications of exopolysaccharides in the dairy industry. Int. Dairy J. 11:759-768.

Elfahri, K. R., T. Vasiljevic, T. Yeager, and O. N. Donkor. 2016. Anticolon cancer and antioxidant activities of bovine skim milk fermented by selected Lactobacillus helveticus strains. J. Dairy Sci. 99:31-40.

Floegel, A., D.-O. Kim, S.-J. Chung, S. I. Koo, and O. K. Chun. 2011. Comparison of ABTS/DPPH assays to measure antioxidant capacity in popular antioxidant-rich US foods. J. Food Compos. Anal. 24:1043-1048.

Gandhi, A., and N. P. Shah. 2016. Salt reduction in a model high-salt akawi cheese: Effects on bacterial activity, ph, moisture, potential bioactive peptides, amino acids, and growth of human colon cells. J. Food Sci. 81:H991-H1000.

Gobbetti, M., F. Minervini, and C. G. Rizzello. 2004. Angiotensin I-converting-enzyme-inhibitory and antimicrobial bioactive peptides. Int. J. Dairy Technol. 57:173-188. 
Gomes da Cruz, A., F. C. A. Buriti, C. H. Batista de Souza, J. A. Fonseca Faria, and S. M. Isay Saad. 2009. Probiotic cheese: Healthpromoting benefits, technological and stability aspects. Trends Food Sci. Technol. 20:344-354.

Hoerr, R. A., and E. F. Bostwick. 2000. Bioactive proteins and probiotic bacteria: Modulators of nutritional health. Nutrition 16:711713.

Jiménez-Guzmán, J., A. Flores-Nájera, A. E. Cruz-Guerrero, and M. García-Garibay. 2009. Use of an exopolysaccharide-producing strain of Streptococcus thermophilus in the manufacture of Mexican Panela cheese. Lebensm. Wiss. Technol. 42:1508-1512.

Kim, Y. M., M. H. Wang, and H. I. Rhee. 2004. A novel $\alpha$-glucosidase inhibitor from pine bark. Carbohydr. Res. 339:715-717.

Kuchroo, C., and P. Fox. 1982. Fractionation of the water-solublenitrogen from Cheddar cheese: Chemical methods. Milchwissenschaft 38:389-391.

Lauritano, C., and A. Ianora. 2016. Marine organisms with anti-diabetes properties. Mar. Drugs 14:220.

Marcone, S., O. Belton, and D. J. Fitzgerald. 2017. Milk-derived bioactive peptides and their health promoting effects: A potential role in atherosclerosis. Br. J. Clin. Pharmacol. 83:152-162.

McSweeney, P., and P. Fox. 1997. Chemical methods for the characterization of proteolysis in cheese during ripening. Lait 77:41-76.

Mohanty, D. P., S. Mohapatra, S. Misra, and P. Sahu. 2016. Milk derived bioactive peptides and their impact on human health-A review. Saudi J. Biol. Sci. 23:577-583.

Nehir El, S., S. Karakaya, S. Simsek, D. Dupont, E. Menfaatli, and A. T. Eker. 2015. In vitro digestibility of goat milk and kefir with a new standardised static digestion method (INFOGEST cost action) and bioactivities of the resultant peptides. Food Funct. 6:2322-2330

Nepomuceno, R. S. A. C., L. C. G. Costa Junior, and R. G. B. Costa. 2016. Exopolysaccharide-producing culture in the manufacture of Prato cheese. Lebensm. Wiss. Technol. 72:383-389.

Oluk, A. C., M. Güven, and A. A. Hayaloglu. 2014. Proteolysis texture and microstructure of low-fat Tulum cheese affected by exopolysaccharide-producing cultures during ripening. Int. J. Food Sci. Technol. 49:435-443.

Park, Y. W. 2009. Overview of bioactive components in milk and dairy products. Pages 1-12 in Bioactive Components in Milk and Dairy Products. Y. W. Park, ed. Wiley-Blackwell Ltd., Ames, IA.

Perry, D. B., D. J. McMahon, and C. J. Oberg. 1998. Manufacture of low fat mozzarella cheese using exopolysaccharide-producing starter cultures. J. Dairy Sci. 81:563-566.

Pessione, E., and S. Cirrincione. 2016. Bioactive molecules released in food by lactic acid bacteria: Encrypted peptides and bio- genic amines. Front. Microbiol. 7:876. https://doi.org/10.3389/ fmicb. 2016.00876.

Picot, L., S. Bordenave, S. Didelot, I. Fruitier-Arnaudin, F. Sannier, G. Thorkelsson, J. Bergé, F. Guérard, A. Chabeaud, and J. Piot. 2006. Antiproliferative activity of fish protein hydrolysates on human breast cancer cell lines. Process Biochem. 41:1217-1222.

Power, O., P. Jakeman, and R. FitzGerald. 2013. Antioxidative peptides: Enzymatic production, in vitro and in vivo antioxidant activity and potential applications of milk-derived antioxidative peptides. Amino Acids 44:797-820.

Ruas-Madiedo, P. J. Hugenholtz, and P. Zoon. 2002. An overview of the functionality of exopolysaccharides produced by lactic acid bacteria. Int. Dairy J. 12:163-171.

Ryan, P. M., Z. Burdíková, T. Beresford, M. A. E. Auty, G. F. Fitzgerald, R. P. Ross, J. J. Sheehan, and C. Stanton. 2015a. Reducedfat Cheddar and Swiss-type cheeses harboring exopolysaccharideproducing probiotic Lactobacillus mucosae DPC 6426. J. Dairy Sci 98:8531-8544.

Ryan, P. M., R. P. Ross, G. F. Fitzgerald, N. M. Caplice, and C. Stanton. 2015b. Sugar-coated: Exopolysaccharide producing lactic acid bacteria for food and human health applications. Food Funct. 6:679-693.

Sah, B. N. P., T. Vasiljevic, S. McKechnie, and O. N. Donkor. 2014. Effect of probiotics on antioxidant and antimutagenic activities of crude peptide extract from yogurt. Food Chem. 156:264-270.

Şanli, T., A. Gursel, E. Şanli, E. Acar, and M. Benli. 2013. The effect of using an exopolysaccharide-producing culture on the physicochemical properties of low-fat and reduced-fat Kasar cheeses. Int. J. Dairy Technol. 66:535-542.

Vadivel, V., A. Nandety, and H. K. Biesalski. 2011. Antioxidant potential and health relevant functionality of traditionally processed Cassia hirsuta L. seeds: An Indian underutilized food legume. Plant Foods Hum. Nutr. 66:245-253.

Yu, Z., Y. Yin, W. Zhao, J. Liu, and F. Chen. 2012. Anti-diabetic activity peptides from albumin against $\alpha$-glucosidase and $\alpha$-amylase. Food Chem. 135:2078-2085.

Yu, Z., Y. Yin, W. Zhao, Y. Yu, B. Liu, J. Liu, and F. Chen. 2011. Novel peptides derived from egg white protein inhibiting alphaglucosidase. Food Chem. 129:1376-1382.

Zisu, B., and N. P. Shah. 2005. Textural and functional changes in lowfat Mozzarella cheeses in relation to proteolysis and microstructure as influenced by the use of fat replacers, pre-acidification and EPS starter. Int. Dairy J. 15:957-972. 